AperTO - Archivio Istituzionale Open Access dell'Università di Torino

\title{
Land suitability map for mountain viticulture: a case study in Aosta Valley (NW Italy)
}

This is a pre print version of the following article:

Original Citation:

Availability:

This version is available http://hdl.handle.net/2318/69320

since 2016-07-05T22:34:21Z

Published version:

DOI:10.1080/17445647.2013.785986

Terms of use:

Open Access

Anyone can freely access the full text of works made available as "Open Access". Works made available under a Creative Commons license can be used according to the terms and conditions of said license. Use of all other works requires consent of the right holder (author or publisher) if not exempted from copyright protection by the applicable law. 


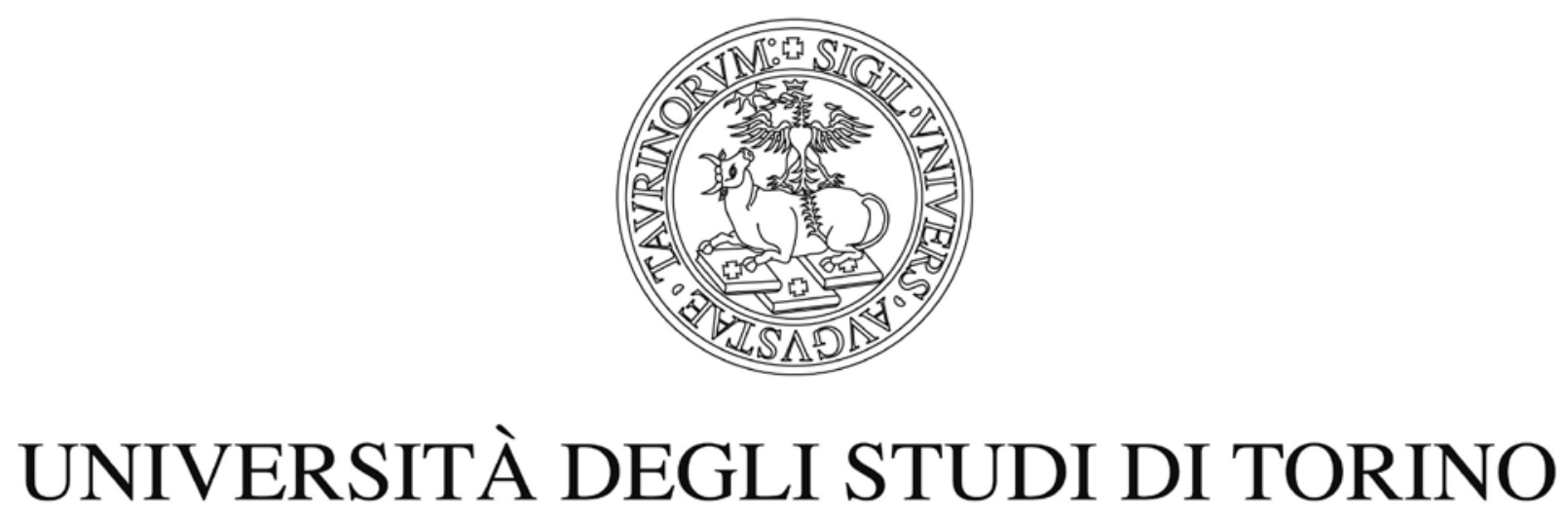

This is an author version of the contribution published on:

Questa è la versione dell'autore dell'opera:

[Journal of Maps, 9:3, 2013, 10.1080/17445647.2013.785986 ]

The definitive version is available at:

La versione definitiva è disponibile alla URL:

http://www.tandfonline.com/doi/full/10.1080/17445647.2013.785986\#.UvtaTPsjpn 


\begin{abstract}
Mountain vineyards are a valuable resource for high quality wine production and landscape conservation. A suitability map (1: 50.000) for mountain vineyard cultivation was created in GIS environment for a study area located in Aosta Valley (NW Italy). We considered the following environmental variables that are known to influence wine production: slope, aspect, altitude, soil, obtaining a suitability map that allowed to identify the areas that can be considered to carry out a sustainable mountain viticulture.
\end{abstract}

\title{
1. Introduction
}

Mountain vineyards are present all across the Alps. Many of them are located at considerable altitudes on terraced slopes (Freppaz et al., 2008). The wine production is often characterized by limited amounts of high quality wines. Steep slopes, limited accessibility, low soil fertility, and dryness may represent limiting factors for vineyard cultivation.

The objective of the Land Suitability Evaluation is to assess the suitability of an area to an agricultural use, i.e. to a specific crop (Calzolari et al., 2006), depending on site and soil properties. Land suitability mapping can be a useful tool for appropriate land management, i.e. to suggest potential uses for marginal agricultural areas such as alpine slopes.

In this work we carried out a GIS-based Land Suitability evaluation for vineyards in an Alpine area located in Aosta Valley (NW Italy).

\section{Materials and methods}

\subsection{Study area}

The study area is located in Aosta Valley $\left(7^{\circ} 30^{\prime} 33^{\prime \prime} \mathrm{E} ; 45^{\circ} 48^{\prime} 01^{\prime \prime} \mathrm{N}\right)$, and covers around $85 \mathrm{~km}^{2}$, mostly within the Saint-Barthelemy watershed. Terraced slopes are quite abundant, and their landscape value is widely recognised (Sandor, 1998). However, terraces have high requirements in terms of maintenance. The terraces main characteristics are very similar to the ones reported 
by Freppaz et al. (2008) who surveyed the terraced slopes nearby in the Lower Aosta Valley (EUINTERREG IIIB project Alpter, www.alpter.net).

\subsection{Suitability analysis}

The suitability of the study area to vineyards cultivation was determined indirectly, i.e. subdividing a set of relevant environmental characteristics (altitude, slope, aspect, geology, soil) into classes, according to the vineyard ecologic needs. The analysis of such classes, obtained in GIS and in a programming environment, led to the definition of the land suitability classification according to the FAO land suitability hierarchy organized into: orders, classes (subclasses, units).

The orders are individuated by a letter: $\mathrm{S}$ for "suitable" and $\mathrm{N}$ for "not suitable", indicating if a specific sustainable agricultural use can be hypothesised or not (e.g suitability to maize, vine, or other crops). Classes define the degree of suitability inside orders, from S1 (suitable, no significant limitations) to S2 (suitable, with moderate limitations), S3 (marginally suitable, severe limitations), $\mathrm{N} 1$ (marginally not suitable, i.e. with limitations that may be surmountable in time but which cannot be corrected with the existing knowledge or under present social conditions to obtain sustainable physical productivity), and N2 (permanently not suitable because of physical limitations). Subclasses and units (when present) provide additional information on management strategies and limitations.

\section{Results and discussion}

\subsection{Agricultural needs; management practices.}

As a general objective, a compromise between agricultural and economic sustainability of the cultivation should be found. Productivity should be contained around $0.35-0.50 \mathrm{t} \mathrm{ha}^{-1}$, in order to ensure: a) high quality standards; b) limited expenses for fertilizers, irrigation and management practices aiming at increasing the productivity; c) relatively scarce market originating a "niche" production, with limited offer and consequently high selling prices. Mechanization may be introduced only when profitable and sustainable, with limited impacts on the environment. The 
management of stone walls and drainage network, and the presence of continuous herbaceous cover should ensure a sustainable management, promoting soil conservation.

\subsection{Environmental variables considered}

Elevation determines the thermal gradient, that in turn strongly influences the plant biology and phenology. The temperature regimes can be related to the agricultural needs of wines using bioclimatic indexes (Mariani and Failla, 2006) such as the Winkler index $\left({ }^{\circ} \mathrm{C}\right.$ day $\left.^{-1}\right)$. For vineyard cultivation, the Winkler index normally ranges from 950 to $2500{ }^{\circ} \mathrm{C}$ day $^{-1}$ (cold and warm regions, respectively), but values from 641 to ca $2000{ }^{\circ} \mathrm{C}$ day $^{-1}$ are reported for mountain sites, including Aosta Valley with $1004-181{ }^{\circ} \mathrm{C}$ day $^{-1}$ according to Mariani and Failla (2006), who highlighted the high plasticity of grape vine in Alpine areas.

The index was computed for the study area from average monthly temperatures (on 10 years time series) using the meteorological station data available in the study area. Based on the calculated index and on local expertise (Zecca O., Institut Agricole Régional, personal communication), the area was subdivided into three elevation classes:

- $\quad$ 490-800 m asl: suitable for many cultivars needing $>950^{\circ} \mathrm{C}$ day $^{-1}$;

- 800-950 m asl: suitable only for adapted cultivars needing less than $950{ }^{\circ} \mathrm{C}$ day $^{-1}$,.

- 950-3490 m asl: not suitable (extreme climatic conditions).

-Slope.

Slope has two relevant effects. A general positive effect is the enhancement of solar radiation, but there is also a potential significant limitation on mechanization, when slopes become very steep. The maximum acceptable threshold is variable and regulated by economical sustainability criteria. In the study area, which has anaverage slope $23,8^{\circ}$, we defined the following 4 classes:

- $\quad 0^{\circ}-10^{\circ}$ : gentle slope, where terracing may be avoided and limited mechanization is widely applicable;

- $\quad 10^{\circ}-25^{\circ}$ : medium slope, need for runoff management, limiting factors for mechanization and higher cultivation costs; 
- $25^{\circ}-35^{\circ}$ : steep slope, partially suitable for cultivation, though with severe limitations; very high production and management costs, sustainable only for high quality productions;

- $\quad 35^{\circ}-88^{\circ}$ : very steep slope, not suitable for vineyard cultivation.

-Aspect

Aspect is a fundamental factor for vineyard cultivation, affecting the amount and intensity of solar radiation reaching the soil. In mountain areas of the $\mathrm{N}$ hemisphere, characterised by low Winkler index values, the South-facing slopes are the best expositions, followed East and West-facing vineyards. North-facing slopes should be excluded due to the insufficient amount of solar radiation. The aspect map was therefore subdivided into three classes:

- $\quad 135^{\circ}-225^{\circ}:$ South-facing slopes

- $\quad 45^{\circ}-135^{\circ}+225^{\circ}-315^{\circ}:$ East and West-facing slopes

- $\quad 315^{\circ}-45^{\circ}$ : North-facing slopes.

All the topographic variables and corresponding threshold values are summarized in table 1.

-Soils

Vineyard growing is strongly affected by soils and the terroir effect. Wine organoleptic quality might vary considerably depending on soil chemical and physical properties. Such influences are quite complex and may vary greatly among cultivars. However, some general relationships between vineyard production and soils can be drawn:

a) Deep soils and high water availability result in a reduction of primary and secondary metabolites of vines, that are known to determine high organoleptic qualities in wine;

b) Shallow soils, skeletal, with limited water availability determine a better wine quality;

c) Nitrogen excess has negative effects on grapes quality;

d) Organic matter input is important on soils with limited fertility. 
In the area considered for this study, the lower sector of slopes includes four soil associations, as classified by the AGRIFORFOOD Department (unpublished data), according to the Soil Taxonomy (Soil Survey Staff, 2006):

- $\quad$ Typic Xeropsamments, mixed (calcareous), mesic;

- $\quad$ Typic Cryopsamment, mixed;

- Typic Haploxerepts, sandy, mixed, mesic;

- $\quad$ Typic Udipsamments, mixed (calcareous), mesic.

The first soil association (Typic Xeropsamments, mixed [calcareous], mesic) occupies most of the altitude range suitable for vineyards. Typic Cryopsamment, mixed, and Typic Haploxerepts, sandy, mixed, mesic occupy smaller surfaces at mid-elevations, while Typic Udipsamments, mixed (calcareous), mesic occupy only a very small portion of the area.

The soil associations mainly differ in their depth, which is generally limited and varies from $35 \mathrm{~cm}$ for Typic Udipsamments to 75 for Typic Xeropsamments, skeletal, with limited aggregation and limited water availability. Despite some differences in their physical and chemical properties, all the soils in the study area can be considered similar in terms of suitability to vineyard growing, i.e. suitable but with limited fertility. Therefore, soils were grouped into a single class, in opposition with non-soil areas (settlements, rocky outcrops, water bodies...).

\subsection{Map creation}

The suitability map was computed by the employment of several GIS tools with a raster-oriented approach. Morphological layers (altitude, slope and aspect) were derived from the digital elevation model at 10 metres cellsize. The DEM is an official product of Regione Valle d'Aosta obtained, in 2005, from an helicopterborne laser scanner survey of the entire region. The layer representing soils, in vector format, was firstly rasterized.

Each layer was reclassified according to table 2. Suitable classes were classified with ascending values ranging from 1 to 3 . Non suitable classes were characterized by a standard value (9). Each class value was been assigned to a different magnitude order (units, tens...) in order to define an 
unambiguous attribution (e.g code 10 for land use 1, code 1 for lithology 1; a resulting sum of 11 means land use one on lithology class 1). The four rasters were then merged, by map algebra, summing cell values. The resulting raster was converted into shapefile format with the aim of improving map's topological structure. For each polygon obtained by the previous conversion the surface was computed and according to final map scale a threshold value was determined in order to spatially filter non significant features. Polygons falling under the defined threshold were, in fact, merged with neighbouring ones with larger surfaces.

In order to optimize the workflow and to allow its deployment, the processing procedure was developed in programming environment where the described tools were grouped and linked in an unique procedure.

Firstly the classification and map algebra procedure were implemented in a Visual Basic program, a user friendly interface was then developed in ArcGis Model Builder environment. The same workflow employed in Visual Basic was repeated and, thank to the Model Builder capabilities, a graphical interface was developed, were the user is allowed to load the four different raster layers, input the reclassification values and select the saving path and file name of the final map. The procedure then performs the sum, the conversion to vector format and the surface computation. Another procedure allows the user to load the final map and to perform the generalisation by defining the threshold value. The main advantage of the Model Builder is the possibility of saving the models into a ToolBox that may be distributed to other users and thus loaded into their ArcGis software, allowing them to perform the processing.

By adopting the system proposed in table 2 we determined orders, classes, subclasses and units.

\subsection{Software}

Data processing has been firstly carried out in ESRI ArcMap 9.3 in order to point out elaboration phases. Then Microsoft Visual Basic 6.0 has been employed to automate the entire procedure. 
Resulting layers have been displayed in the map layout by employing again ESRI ArcMap 9.3 capabilities.

\section{Conclusions}

Suitable areas were concentrated in the lower portion of slopes where favourable climate, exposure and limited slope may support vine cultivation without unbearable effort (both from the economic and environmental side). Positive experiences in the same region confirm the result of this research, showing that good productions can be achieved in such environmental conditions.

\section{Acknowledgements}

This work was funded by the EU-INTERREG IIIB project Alpter, www.alpter.net (authorization number for cartographic material used: 07.06.2006 Aut.1025). We would like to thank Dr. Odoardo Zecca from IAR (Institut Agricole Régional - Aosta) for the valuable comments and help in the revisions.

\section{References}

Calzolari C., Costantini A.C. E., Venuti L., 2006. La valutazione dei suoli e delle terre: storia, definizioni e concetti. Metodi di valutazione dei suoli e delle terre. Edizioni Cantagalli, 3-47.

Freppaz, M., Agnelli, A., Drusi, B., Stanchi, S., Galliani, C., Revel Chion, V., Zanini E., 2008. Soil quality and fertility: studies in the Valle d'Aosta. In Terraced landscapes of the Alps. Projects in Progress. (Eds. Fontanari E., Patassini D.) Marsilio - Venice - IT, pp 37-39.

Mariani, L., Failla, O., 2006. Agroclimatic characterisation of European mountain viticultural areas. Proceedings First International Congress on Mountain Viticulture. Saint Vincent (AO).

Sandor, J. A., 1998 "Steps toward Soil Care: Ancient Agricultural Terraces and Soils," in Transactions of 16th International Congress of Soil Science, Montpellier, France, 1998 (Montpellier).

Soil Survey Staff: Soil taxonomy, Tenth Edition, USDA, Washington DC, USA, 2006. 


\section{Map Design}

The suitability map was computed by the employment of several GIS tools, available in ESRI ArcMap 9.3, with a raster-oriented approach. Morphological layers (altitude, slope and aspect) were derived from the regional digital elevation model, surveyed by airborne laser scanner in 2005 , available in grid format with 10 meter cell size. The elevation model has been employed as is in order to represent altitude and then it was employed in 3D processing to obtain slope and aspect. The layer representing soils, in vector format, was firstly rasterized.

Each layer was reclassified according to table 1. Suitable classes were classified with ascending values ranging from 1 to 3 . Non suitable classes were characterized by a standard value (9). Each class value has been assigned to a different magnitude order (units, tens...) in order to define univocal attribution.

The four rasters were then merged, by map algebra, summing cell values. The resulting raster was converted into shapefile format with the aim of improving map's topological structure. For each polygon obtained by the previous conversion the surface was computed and according to final map scale a threshold value was determined in order to spatially filter non significant features. Polygons falling under the defined threshold were, in fact, merged with neighbouring ones with larger surfaces.

In order to optimize the workflow and to allow its deployment, the processing procedure was developed, in programming environments, where described tools were grouped and linked in an unique procedure .

Firstly the classification and map algebra procedure were implemented in a Visual Basic program, A user friendly interface was then developed in ArcGis Model Builder environment (Figure 1). The same workflow employed in Visual Basic was repeated and, thank to the environment feature, a graphical interface was developed, were the user is allowed to load the four different raster layers, input the reclassification values and select the saving path and file name of the final map. The 
procedure then performs the sum, the conversion to vector format and the surface computing. Another procedure allows the user to load the final map and to perform the generalisation by defining the threshold value. The main advantage of the Model Builder is the possibility of saving the models into a ToolBox that may be distributed to other users and thus loaded into their ArcGis software, allowing them to perform the processing.

By adopting the system proposed in table 4 we determined orders, classes, subclasses and units.

The resulting layer has then been displayed in a A3 format layout and provided with additional layers as the 1:50000 technical regional map and the hillshade, computed from the previously cited elevation model, in order to improve the graphical aspect of the final map.

Two additional map have also been added a first one describing study area's location in Italy, provided with a hillshade in background obtained from SRTM free data, and a second showing study area elevation by displaying the previously described elevation model. 